\title{
On the Impacts of Negotiated English Listening Teaching on Learners of English in College
}

\author{
Tang Li-hua \\ China West Normal University \\ Nanchong, Sichuan 637002
}

\begin{abstract}
The study has developed a negotiated syllabus incorporated in college English listening teaching. Results indicate that this type of teacher-student negotiated intervention in the teaching-learning process has been perceived to be effective by both teachers and students. Students are observed to appreciate the learning process with negotiating with both teachers and peer and improve their listening comprehension greatly.
\end{abstract}

Keywords-Negotiated teaching; negotiated syllabus; listening comprehension

\section{INTRODUCTION}

In recent years, the Ministry of education has conducted the examination of the four and six levels and the direction of College English teaching reform. It can be seen that listening, as a course, has been paid more and more attention by educators. However, the current model of College English teaching is based on the characteristics of traditional teaching. The number of students is large, the teaching hours are small and the classes are large [1]. As the students enter this stage, listening, as the weakest link, still cannot be strengthened and promoted in time. The listener should be required to completely know the content of the message, and the speaker should accordingly repeat, simplify or explain the content. Generally speaking, in the traditional teaching, teachers will not explain their syllabus to students, and students will not explain their understanding of classroom teaching activities and their relationship with their learning programs. Due to the lack of coordination, the learning process may be inhibited, interrupted or delayed. Therefore, it is urgent to formulate an effective and targeted teaching strategy for listening class teaching [2]. In the course of negotiation teaching, the teaching content is enriched and perfected constantly. Foreign language teaching has been continuously improved and optimized, and students' autonomy has been fully developed. The teacher knows more about the actual situation of the students, and the relationship between the teacher and the student is no longer the relationship between knowledge inculcation and passive acceptance. Negotiation teaching reflects the important role of teacher, and it also realizes learners' center, and achieves the excellent situation between teachers and students in foreign language teaching [3].

\section{A SURVEY OF NegOtiation TEACHING AT HOME AND ABROAD}

As early as in 1980, the concept of "negotiation" was introduced in academic circles. Long thought negotiation refers to the process of modifying interactive discourse in order to break through communication barriers. In recent years, more and more scholars have pointed out that negotiation is essential to successful language learning. Negotiation between teachers and students has become an important topic in the field of language learning. Atkinson called attention to the research on the interaction process and interactive environment, in order to better understand the environment of the second language acquisition under the interactive negotiation [4-5]. Halls and Verplaetse pointed out that the classroom activities are based on the basis of the interaction between teachers and students. As they say, classroom discourse is especially important in creating a learning environment and promoting individual learners' progress and development.

In recent years, the research of negotiated interaction is rising, which attracts the attention of Chinese scholars. Liu Xuehui introduced and analyzed the two concepts, interactive negotiation and interactive adjustment. She divided the negotiation into three categories, meaning negotiation, formal consultation and content negotiation. The proportion of negotiation interaction in the total classroom interaction was investigated. Zhou Junping expounded the role of deliberative classroom interaction in the development of learners' language. He emphasized the practical significance of negotiation teaching in Chinese College English classroom teaching. Then he discusses the relationship between culture and negotiation boon lay students' communicative competence and the role.

By now, the research on the interaction between teachers and students in the second language classroom environment has achieved certain results, showing a certain degree of maturity. But in the foreign language classroom environment, the relevant research is seriously missing. In China, the research work is still in its infancy [6-7]. There is no systematic in-depth investigation and study. Existing research has no support for rational thinking and practical verification. Therefore, the purpose of this study is to optimize the negotiation teaching, create more opportunities for students to participate in language practice, and improve the effectiveness of classroom teaching. 


\section{RESEARCH DESIGN}

\section{A. Object of Study}

The subjects were 126 first-year non-English Majors at the China West Normal University. The author began to use the design method before and after the experiment to carry out exploratory empirical study. First, the same listening pre-test was conducted to all two groups of students in the independent class. The content is college English test band four listening comprehension test, with a total score of 35 . The pretest scores of independent samples in parallel class $\mathrm{T}$ test results are shown in table 1 .

TABLE I. INDEPENDENT SAMPLE TEST RESULTS OF PRE-TEST PERFORMANCE OF TWO STUDENTS IN PARALLEL CLASS

\begin{tabular}{|c|c|c|c|c|}
\hline group & average & standard deviation & $\mathrm{t}$ & $\mathrm{P}$ \\
\hline Control group $(\mathrm{n}=58)$ & 16.47 & 4.187 & -.101 & .917 \\
\cline { 1 - 3 } Experimental group $(\mathrm{n}=68)$ & 16.57 & 3.895 & & \\
\hline
\end{tabular}

From the statistics described in Table 1, the overall mean score of pre-test in the control group was slightly lower than that in the experimental group. However, the independent sample $t$ test showed that there was no significant difference between the pretest average scores of the students in the two parallel classes. Therefore, it can be inferred that the students in the control group and the experimental group have the same level of English listening ability, and the experiment can be carried out.

\section{B. Research Design and Process}

This study used quantitative and qualitative research methods, and the implementation time is from October 2016 to February 2017, for 15 weeks. Before listening, teachers ask students to answer the following questions: 1) what are your listening goals? What do you want to hear most in your listening class? Please list the subjects you are interested in. (2) what kind of listening activities are you most interested in participating in class learning? 3) Do you think what kind of evaluation method can reflect your actual listening level? Then the new edition of College English listening and speaking course in the first unit of the first volume are listed as an example. It elaborates on how to encourage students to participate in classroom decision-making consultation. This unit consists of three parts: Part, A, listening skills training, Part $\mathrm{B}$, listening and speaking training parts, and Part $\mathrm{C}$ listening test. The teacher briefly introduces the three parts before class [8-9]. And then she encourages students to preview before class. In the end, students and teachers will consult in class to decide which parts are detailed, which parts are not even spoken and what can be extended to the classroom. Students are encouraged to take notes or summaries in written form after each listening session, and hand them in once a week. Teachers can use feedback from students to modify their own teaching experience. With questions or ideas, the teacher can communicate with students individually, in writing, or in short messages.

\section{Classroom Presentation}

The content and process of teaching after consultation can meet the requirements of students to a great extent, and then stimulate students' interest in learning. The following is an English Negotiation teaching model [10-12]. Teacher Liu Heng and Zheng Zhilian present a fragment of the listening consultation class:
T: Morning class! First let's have five minutes to pre-view the listening practice materials in Unit Three. After reading, please tell me which part you want to listening this class, ok?

\section{Ss: Ok!}

Five minutes silence.

T: Have you finished? Ok, now tell me what's your opinion?

S1: I think all parts of Unit Three are a little difficult to us. I hope teacher can omit this part and just tell us the answers to the listening exercise so that we can try to practice them after class when we have time.

S2: I'm afraid not. I think we can try part one and part two in the first class, and then try other materials in the second class.

\section{S3: I agree with S2.}

S4: Anything is ok to me. I just hope the listening materials are not too difficult. I don't like too many new words appearing during listening.

... (Negotiation lasts about five minutes.)

T: Ok, so we will practice part one and part two in the first class. And the answers to the part three and part four will be told to you after class by the monitor. In the second class, we will go on listening to some English songs and dialogues from movies. If any problem, please tell me at any time. Is that all right?

\section{Ss: All right! (loudly and happily)}

Class really begins...

Negotiation will still go on when necessary...

T: Do you want to try part one again? ... How about Part two? Is that difficult to you? ...

Ss: Once again please... Can the answers to part two be read aloud to the whole class?...

T: Which songs do you like best? ... We'll listen again and try to sing with it without looking at the translation.

$$
\text { Ss:... }
$$$$
\text { ... }
$$

T: Any other listening materials do you have taken to the class? Let's share it. 


$$
\text { Ss:... }
$$$$
\cdots
$$

T: Next time, I hope you can preview Unit Four and choose the right part you want to listen. I also hope we can share the listening practice materials together. You can give them to me to have a look firs. Especially pay attention please, S6, S7, S8! It's your turn to share your practice materials in the next class. Don't forget. So much for today. Goodbye! See you next time.

\section{Ss: See you.}

The teachers also felt the change of the students' interest in the experimental class. Many students express keen interest in the listening course in their diaries.

\section{Research Results and Analysis}

After one semester, the results of students of the experimental group before and after hearing the measured performance of the paired sample test are shown in table 2 .

TABLE II. THE SCORES OF THE EXPERIMENTAL GROUP WITH THE TEACHING MODEL BEFORE AND AFTER THE CONSULTATION

\begin{tabular}{|c|c|c|c|c|}
\hline & scores & standard deviation & c & P \\
\hline $\begin{array}{c}\text { Pre-test in experimental } \\
\text { group }\end{array}$ & 16.57 & 4.001 & .787 & .001 \\
\cline { 1 - 2 } $\begin{array}{c}\text { Post-test in experimental } \\
\text { group }\end{array}$ & 20.89 & & & \\
\hline
\end{tabular}

From the statistics described in Table 2, the students in the experimental group have significantly improved their listening ability after one semester of negotiation and listening training.
Subsequently, the author compares the listening test results of the experimental class and the control class according to different teaching modes, and the results are shown in Table 3.

TABLE III. COMPARISON OF LISTENING TEST RESULTS BETWEEN THE EXPERIMENTAL CLASS AND THE CONTROL CLASS

\begin{tabular}{|c|c|c|c|c|}
\hline & scores & standard deviation & $\mathrm{t}$ & $\mathrm{P}$ \\
\hline Pre-test in control group & 18.68 & 3.181 & -3.014 & .003 \\
\hline Post-test in control group & 20.89 & 2.050 & & \\
\hline
\end{tabular}

Through the comparative analysis, we can see that after a semester of listening teaching, the students of the two classes have different levels of listening. By independent sample t test, it was found that the final class of the students who had negotiated teaching was better than the students in the nonexperimental class [13-14].

In the experimental group, 20 students were randomly selected to have a talk about the negotiated listening teaching model. Interviews were conducted and all the students agreed with the listening model. Negotiation teaching enriches the teaching methods and contents and stimulates their learning enthusiasm. They are willing to spend more time listening to practice than they used to. They have a more serious and responsible attitude in practice, which promotes their independent learning ability and strengthens mutual trust between teachers and students. When it comes to opinions and suggestions about this new type of teaching, their feedback is more valuable: 1) hope to avoid passive participation in consultation. Because they are too familiar with the traditional classroom teaching model, sometimes they participate in class negotiation and feels himself in a passive and obedient learning position [15-16]. They do not have the autonomy of learning in the course of consultation. Their attitude is not positive, and lack of self-confidence. They hope that teachers will encourage students to ask questions and guide them to prepare for class negotiations. 2) Hope that the content of consultation learning should not become mere formality. They are sometimes very lively, but in fact they do not take the initiative to think about the purpose of this study. They do not have the perfect and full of spiritual learning mood if they just stay on the surface of the excitement.

\section{CONCLUSION}

Based on the above research, we can conclude that the negotiated listening teaching model can improve students' listening comprehension ability. Negotiation teaching enables teachers to better understand the students' learning needs, learning background and their practical learning ability, so that the whole classroom activities are more optimized. Through consultation, the enthusiasm of students to learn English has been aroused, and their sense of responsibility has been increased, and their listening comprehension ability has been improved. English teaching is not only in teaching, but also in learning. Teachers and students are the subject of both. In classroom teaching activities, the status of both can not be ignored. Negotiation teaching effectively solves the problem of whether the teacher is the main part or the student is the center of the English teaching.

\section{ACKNOWLEDGMENT}

Author information: Lihua Tang, female (1979.4--), Han. Nanchong, Sichuan. Master's degree, Associate Professor, research field: English Teaching.

The paper was supported by the talent foundation project of China West Normal University (No. 17YC073).

Address: in the Shi Mashan apartment Nanchong City District Sichuan province. 


\section{REFERENCES}

[1] Krashen, SD. 1981. Second Language Acquisition and Second Language Learning [M]. Cambridge:cambridge university Press

[2] Hailong Xiao,Xideng Zheng,2003,A Study of Negotiated Learning [J],'Developmental Education rResearch",(11):32-35 .

[3] Long,M.H. 1980. input, interaction, and second language acquisition. Unpublished doctoral dissertation, University of California, Los Angeles.

[4] Rulon, K. A,\&Mc Creary, J. 1986. Negotiation of con-tent: Teacher fronted and small -group interaction[J]. Talking to learn, 1986:182-199.

[5] Breen M \& Littlejohn A. 2000 . classroom Decision making[M]. Cambridge:cambridge university Press.

[6] Atkinson, D. 2002. Toward a sociocognitive approach to second language acquisition[J]. The Modern Language Journal, (86): 525-545.

[7] Hall, J. K.\&Verplaetse, L. S.2000. The development of second and foreign language learning through classroom interaction[J]. Second and foreign language learning, 2000(1):1-20.

[8] Xuehui Liu,2005. Second language acquisition in a classroom setting: theoretical frameworks and analytical units [ $\mathrm{J}]$,'Foreign language and foreign language teaching",(6):25-29

[9] Xuehui Liu,2007. Negotiation, interaction and timely output: a timely exploration of classroom language [ $\mathrm{J}$ ],'Foreign language and foreign language teaching",(11):25
[10] Junping Zhou,2006,Teacher talk and second language acquisition [J]," foreign language teaching"(5):69-73

[11] Wenli fang,2005, Meaning negotiation and foreign language focused Task-based Teaching [J],"Foreign language and foreign language teaching"(1):23-27.

[12] Aijun Liu, 2009 , Research on listening and speaking teaching mode in Multimedia Network Environment [J],'foreign language world"(5):6 3 64 .

[13] Liuheng,Zhen Zhinian,2 0 08,Study on English Listening Classroom Teaching of Higher Vocational Students' negotiating [J],'Journal of Jixi University"(5): 8

[14] Kefu Lang,Wangling,2 01 0,Research on the motivation of autonomous learning under the Internet Teaching Model [J],"foreign language world"'(3): 16 .

[15] Dingfang Su,2013,Comprehensive curriculum objectives and quality of English Majors -- a review of the third foreign language teaching competition held by the foreign teachers' Association Cup in China[J],"foreign language world"(2):43-49.

[16] Dingfang Su,2012,College English teaching competition and teacher development[J],"foreign language world"(3):34-41. 